\title{
Place management of a creative city: the case of Izmir
}

\section{Onur Mengi*}

Department of Industrial Design, Izmir University of Economics, Turkey

Email: onur.mengi@ieu.edu.tr

*Corresponding author

\section{S. Bahar Durmaz Drinkwater and Aslı Ceylan Öner}

Department of Architecture, Izmir University of Economics, Turkey

Email: bahar.durmaz@ieu.edu.tr

Email: asli.oner@ieu.edu.tr

\section{Koray Velibeyoğlu}

Department of City and Regional Planning, Izmir Institute of Technology, Turkey Email: korayvelibeyoglu@iyte.edu.tr

\begin{abstract}
This study investigates how place management is used to render a creative city through the combination of soft factors as intangible characteristics and hard factors as tangible characteristics of the built environment. The study focuses on Izmir, Turkey; exploring its potential as an emerging creative city. The methodology is a descriptive analysis of recent urban design and planning activities of creative cities, reviews projects and strategies in Izmir. Findings provide a framework for place management tools and their strategic use for integration of art, design, creativity and knowledge in creative cities. Place management is used as a tool for image building and identity enhancement, and for quality of place to attract creative and knowledge workers. In the case of Izmir, hard factors triggered the formation process whereas soft factors have taken strengthen the initiative. However, both of them are yet not strong enough to creative public awareness and critical mass.
\end{abstract}

Keywords: creative city; design city; place management; hard factors; soft factors; Izmir; place management; identity enhancement; image building, social networks, creative public awareness.

Reference to this paper should be made as follows: Mengi, O., Drinkwater, S.B.D., Öner, A.C. and Velibeyoğlu, K. (2017) 'Place management of a creative city: the case of Izmir', Int. J. Knowledge-Based Development, Vol. 8, No. 3, pp.271-291.

Biographical notes: Onur Mengi has BURP MUD and PhD in City Planning. $\mathrm{He}$ is an Assistant Professor in the Department of Industrial Design in Izmir University of Economics, Izmir, Turkey. He is also the Coordinator of the Design Management Master Program in the Graduate School. His primary 
research areas are creative and cultural industries, strategic management in creative industries and ecology of industry clusters. He carries out research projects on the specific topics of urbanism, urban theories, and design projects including urban design, product and service design.

S. Bahar Durmaz Drinkwater has a BArch, MUrbanDesign and $\mathrm{PhD}$ in Architecture. She is an Assistant Professor at Izmir University of Economics, Turkey and a Research Associate at Cambridge Architectural Research, England. She is an Architect who has experience in teaching, research and architectural practice. She has a PhD in Architecture from the University of Nottingham. It explored the quality of place and design/planning process of creative neighbourhoods. Her current research is focused on urban architecture, public place, urban change, social sustainability and design process.

Aslı Ceylan Öner has a BArch, March and PhD in Environmental Design and Planning. She is an Assistant Professor at Izmir University of Economics in Turkey and the Head of Architecture Department. Her core research interests are globalization, global urban networks, planning and development of built environment in global cities, innovation systems, city branding through art and architecture, and comparative urbanisation. She has a Master's degree in City Space and Society from the London School of Economics and Political Science where she developed her core research interest of globalization. She also has a Master's degree in Architecture from the Ball State University in Indiana, USA. She completed her Doctoral degree in Virginia Tech in Environmental Design and Planning with a focus on the locational distribution of global advanced producer service firms within the polycentric US metropolitan areas.

Koray Velibeyoğlu has a BURP MUD and PhD in City Planning. He is an Associate Professor in the Department of Urban and Regional Planning, Izmir Institute of Technology. $\mathrm{He}$ is also the Director of Center for Lifelong Learning. His research spans urban design, planning history, knowledge management, local asset-based development, urban ICT policy-making and knowledge-based development processes. He is the Project Manager of Izmir Peninsula Sustainable Local Development Project.

This paper is a revised and expanded version of a paper entitled 'Place management of a creative city: the case of Izmir', presented at the 9th Knowledge Cities World Summit, Vienna, Austria, 12-13 October 2016.

\section{Introduction}

For the last decade, the diffusion of the new economic restructuring based on creative and knowledge intensive industries as well as information and communication technologies (ICT) has entailed the emergence a number of new urban concepts. These include creative city, innovative city, knowledge city, as a means for economic (re) development and international recognition among cities based on clustering of businesses in high-tech industries, businesses in art, culture and design. Within this list, creative cities refer to the city economies with agglomeration of particular businesses, producing intellectual property mostly in the creative realm. Architecture, interior design, graphic design, fashion design, craft production art, marketing, advertising and publishing are examples of highly clustered businesses in creative cities (Lash and Urry, 1994; Montgomery, 
2005). Creative cities and their formations contain both hard and soft factors. While hard factors have been extensively studied over the past decades, there is currently a growing need to contribute to existing research practice on creative cities by focusing on soft factors. Together with the hard factors, soft factors create a strong base of place management of creative city formation. Therefore, this study explores the soft and hard factors as components of place management of creative cities. After having reviewing the well-known creative cities/districts/precincts in different scales and creative/knowledge workers, typologies, needs and wants, this research constructs a summary of the place management components for creative cities and creative workers. Following, it regards place management from the soft and hard infrastructural perspectives and builds a content (so-called 'factors') consisting of identity enhancement, social interaction and networks as 'soft factors'; place making: quality of place and place branding and incubation of creativity as 'hard factors'.

The scope of this paper is the development and inventory of assets that defines the soft and hard factors in the 'design city' vision of Izmir focusing on the socio-cultural, physical and institutional aspects. The quantitative economic and demographic indicators have not been integrated into the scope of this study. However, a comprehensive future research agenda will aim to understand how these indicators, including employment in design-related industries, number of firms in design businesses, unemployment rate, population growth rates according to age groups, the number of cultural activities, have changed after Izmir was designated as 'design city' in 2009, looked in comparison to other major cities such as Istanbul and compared to the nation as a whole. The case study investigates the availability and characteristics of the soft and hard factors as components of place management in Izmir, regarding the recent developments and assets of Izmir. This descriptive analysis aims to bring together all the strategic decisions and organic developments towards achieving the 'design city vision' of Izmir, which has recently been proposed by the city authorities. However, since this concept of 'design city' is not yet discussed in the literature, this paper constructs its arguments based on the creative city concept that can be taken as an umbrella term for the city visions that departs from knowledge, art, creativity and design. In addition, the paper presents the findings of the research project called Izmir Knowledge Society-based Development Strategy, funded by Izmir Development Agency (IZKA, 2013b) as part of Izmir Regional Development Plan 2014-2023. The findings of this research project are used for understanding İzmir's creative workers' perception of quality of place. The case study findings reveal recent developments in Izmir with regards to the most recent planning and design efforts in terms of identity enhancement, social interaction and networks, place making: quality of place and place branding and incubation of creativity.

\section{Creative cities}

Creativity has been both a major driver and a component of today's new knowledge-based economy, in which branding places is important attracting global flows of investment and talent (Cabrita et al., 2013; Yigitcanlar et al., 2016). Along with the new economic trends that defines a transition from Fordism to a service-oriented economy (Yagoubi and Tremblay, 2017), the emergence of the creative industries has enabled entire design sectors to develop products around creativity and creativity for the 
management of business has become critical (Hesmondhalgh, 2002). Many institutions and organisations, which provide a global platform for cities around the world to share their own experiences and create new opportunities for followers have launched initiatives to strengthen the creative city vision: Vancouver's Office of Cultural Affairs started the Creative City Network of Canada in 1997; Partners for Livable Community, based in Charlotte, North Carolina, formed the creative cities initiative in 2001; UNESCO launched its Creative Cities Network in 2004; Osaka City University setup a Japanese Creative Cities Network in 2005; the British council joined with the Australian council for the arts to present a forum, making creative cities in 2008 and finally in 2009, the British Council established the Creative Cities project involving the UK and 12 countries in East Asia. The concept of creative city was originally put forwarded by Charles Landry. Landry (2000) asserts that the formation of creative city involves open-mindedness and motivation to take risks, having a long-term objective with considerate strategies, a capacity to work with local uniqueness and a willingness to listen and learn. These qualities first enable people, projects, organisations and then small spaces, districts and ultimately cities to become creative. Bulu (2011) asserts that in searching for their ideal jobs, people also look for an ideal city. In the context of creative cities, identity promotion is crucial since creative city designates geography where creative, talented and diverse people come together (Grant and Chuang, 2012). Since the creative city content is visible in different scales, the place management is worth mentioning as a frontier. For Landry (2000), creative cities can also be regarded as the centres of the hard infrastructure of creative industries (e.g., buildings, roads, galleries, museums, libraries, universities) and as the centres of soft infrastructure, which defines its atmosphere and regulatory organisation, as well as the relational assets associated with trust, mutuality, exchange of creativity and knowledge (Landry, 2000). The transformation of such hard infrastructures is highly argumentative. Since the revitalisation of ex-industrial buildings as studios and flats by creative producers and their renewal, adaptation and redevelopment for creative production and consumption are being studied theoretically in the urban regeneration literature. Examples of practice, creative cities are London, Glasgow, Hamburg, Berlin, Barcelona, Milan, New York, Montreal, Toronto, San Francisco and Vancouver. In these cities, new spatiality of creative city formations has emerged as a revival of former manufacturing sites or as a new phase of the urban services under new economy, as a rediscovery of live-work facilities and the shared workspaces within former industrial zones and buildings (Evans, 2009). Such new phases indicate design, as well as older manufacturing techniques, inherited knowledge on arts and crafts, but served as an appealing dimension of new urban development.

As previously given argument suggests, creative city idea is intermeshed with design practices. For the urban and regional scale developments that flourish particular creative industries, the geographies in the USA, the UK, Europe, Far East and Australia are mentioned as highly containing the practice of creative city formation. The leading creative industry formations, as well the presence of creative workers in the USA are concentrated specifically in Washington, DC, Austin, San Francisco, Seattle, Boston, Chicago, Minneapolis and Denver where there is high potential for entrepreneurship and technological infrastructures. In the UK, London and the southeast region, as well as, more recently Ireland have shown considerable developments for achieving the creative city (DCMS, 2001). Particularly, creative industries seem to have concentrated along the peripheries of Central London and also in Central London itself (Durmaz, 2015; 
Gornostaeva and Cheshire, 2003; Hutton, 2006). Additionally, Amsterdam and Helsinki appear as major cities where the design-based activities and creative work occur. Berlin, Oslo, Milan and Paris are also mentioned as creative cities in the European context as well. Tokyo and Hong Kong (Yusuf and Nabeshima, 2005); Vancouver with the clustering industries of advertisement, graphic design, interior design, architecture and fashion in Canada, especially around the regions of Yaletown and Gastown (Hutton, 2006) appear as major design capitals. Australia, Melbourne and Sidney contain high concentration of creative workers in the creative industries. Briefly, recently emerged well-known examples of creative environments in scales of regions, districts, neighbourhoods, clusters, precincts and hubs around world can be summarised as in Table 1.

Table 1 Creative environment in different scales

\begin{tabular}{|c|c|c|c|}
\hline Name of the cluster & Country & Scale & Dominant cluster type/user profile \\
\hline Suzhou & China & City & Crafts and folk art \\
\hline M50 Art district & China & District & Art galleries and studios \\
\hline Red town & China & Building & Work stations and studios \\
\hline 1993 Millfun & China & Building & $\begin{array}{l}\text { Visual communication, fashion } \\
\text { experience, film and TV creativity, } \\
\text { display of creative works }\end{array}$ \\
\hline Bridge 8 & Shanghai, China & Building & Workplace for artists and designers \\
\hline Famous 798 & Beijing, China & District & Work stations and studios \\
\hline $\begin{array}{l}\text { Insadong and } \\
\text { Daehagno }\end{array}$ & $\begin{array}{c}\text { Seoul, } \\
\text { South Korea }\end{array}$ & District & $\begin{array}{l}\text { Exhibition and galleries for artists, } \\
\text { cultural quarter }\end{array}$ \\
\hline Arabianranta & Helsinki, Finland & Building & Living lab \\
\hline Cinecitta & Rome, Italy & District & Film industry \\
\hline 22@ & Barcelona, Spain & District & $\begin{array}{l}\text { Media, information and } \\
\text { communication technologies (ICTs), } \\
\text { medical technologies, energy and } \\
\text { design. }\end{array}$ \\
\hline $\begin{array}{l}\text { Kreuzberg and } \\
\text { Prenzlauer }\end{array}$ & Berlin, Germany & District & $\begin{array}{l}\text { Work environment for artists, } \\
\text { designers, IT sector, architects, } \\
\text { designers, academics, lawyers, } \\
\text { journalists and bloggers }\end{array}$ \\
\hline Arts Electronica & Linz, Austria & & Media arts \\
\hline Museum Quarter & Vienna, Austria & District & $\begin{array}{l}\text { Entrepreneurs, a modular-action } \\
\text { platform for independent small } \\
\text { institutions, culture offices and } \\
\text { temporary initiatives. }\end{array}$ \\
\hline Museum Quarter & $\begin{array}{l}\text { Rotterdam, } \\
\text { Netherlands }\end{array}$ & District & $\begin{array}{l}\text { Promotion of local culture, } \\
\text { creative/cultural industries }\end{array}$ \\
\hline $\begin{array}{l}\text { The } \\
\text { Westergasfabriek }\end{array}$ & $\begin{array}{l}\text { Amsterdam, } \\
\text { Netherlands }\end{array}$ & Building & $\begin{array}{l}\text { Rental workplaces, venues for, film, } \\
\text { theatre and exhibition facilities }\end{array}$ \\
\hline Soho & London, UK & District & Film industry \\
\hline Soho & $\begin{array}{l}\text { New York City, } \\
\text { USA }\end{array}$ & District & Art galleries and artists \\
\hline
\end{tabular}


Table 1 Creative environment in different scales (continued)

\begin{tabular}{|c|c|c|c|}
\hline Name of the cluster & Country & Scale & Dominant cluster type/user profile \\
\hline Broadway & $\begin{array}{c}\text { New York City, } \\
\text { USA }\end{array}$ & District & Stage arts \\
\hline Tribeca & $\begin{array}{c}\text { New York City, } \\
\text { USA }\end{array}$ & District & $\begin{array}{l}\text { Formerly textile and cotton trade; } \\
\text { Today; photography, film industry, } \\
\text { fashion and various activities }\end{array}$ \\
\hline Silicon valley & California, USA & District & Computing and electronics industries \\
\hline Liberty village & Toronto-Canada & District & $\begin{array}{l}\text { Creative work and live environment } \\
\text { for artists, corporate creative } \\
\text { workers, }\end{array}$ \\
\hline Tohu & Montreal-Canada & & $\begin{array}{l}\text { Creation factory, artist-run centre; } \\
\text { research and creation that also acts as } \\
\text { a museum, a theatre and an } \\
\text { environmental centre }\end{array}$ \\
\hline $\begin{array}{l}\text { ICT Cluster ve } \\
\text { Distillery District }\end{array}$ & Montreal-Canada & District & Information technologies \\
\hline Beyoğlu & Istanbul-Turkey & District & Film industry \\
\hline Beşiktaş-Şişli & Istanbul-Turkey & District & Fashion industry \\
\hline
\end{tabular}

Additionally, creative cities can be regarded as magnets for talented immigrants and generators of wealth. A positive city image can offer a good international position for cities. Landry (2000) and Florida (2002) argue that cities must compete with each other in order to attract and retain both investment and talent. Jensen (2005) discusses place branding as a globally recognised strategy for competition among cities and other advantages include investment and talent and to sustain economic and social vitality (Prophet, 2006). Regarding the above list, common characteristics of creative cities, regions and districts can be shortly summarised in Table 2 .

Table 2 Creative city characteristics

\begin{tabular}{ll}
\hline Soft factors & \multicolumn{1}{c}{ Hard factors } \\
\hline $\begin{array}{l}\text { Creative potential, open-mindedness and } \\
\text { motivation of creative atmosphere and work }\end{array}$ & Quality of place \\
$\begin{array}{l}\text { Local uniqueness and identity } \\
\text { Exchange of ideas, knowledge and creativity }\end{array}$ & $\begin{array}{l}\text { Place branding } \\
\text { Presence of the hard infrastructure of creative } \\
\text { industries }\end{array}$ \\
$\begin{array}{l}\text { Presence of place identity that defines its } \\
\text { spatial atmosphere }\end{array}$ & $\begin{array}{l}\text { Regional policy enterprises to attract and retain } \\
\text { creative industries }\end{array}$ \\
Educated and ethnically diverse population & $\begin{array}{l}\text { Interdependency and agglomerations of creative } \\
\text { industries }\end{array}$ \\
Social proximity and diversity & $\begin{array}{l}\text { Use of the urban design and architectural design } \\
\text { The distinctive urban locations (the abandoned }\end{array}$ \\
Networks & $\begin{array}{l}\text { or obsolescent districts of post-industrial cities, } \\
\text { use of urban design and so forth) }\end{array}$ \\
Bultural capital & Branding through physical interventions \\
\hline
\end{tabular}


These given characteristics explained above will be conceptualised and discussed as components under the soft factors and hard factors of the place management in the following section.

\section{Place management components}

Landry (2000) has drawn attention to the significance of creativity in modern cities and regions, where he makes emphasis on the combination of hard infrastructure, or the network of building and institutions that constitute a city or a region and soft infrastructure as "the system of associative structures and social networks, connections and human interactions, that underpins and encourages the flow of ideas between individuals and institutions" [Landry, (2000), p.133]. In addition, Durmaz et al. (2008) argues that the building blocks of creative city are as follow: the existence of the creative industries, as the economic base, existence of a creative community as the social base and the planning/design strategies as place-based approaches to building creative cities (Figure 1).

Figure 1 Creative strategies put into context (see online version for colours)

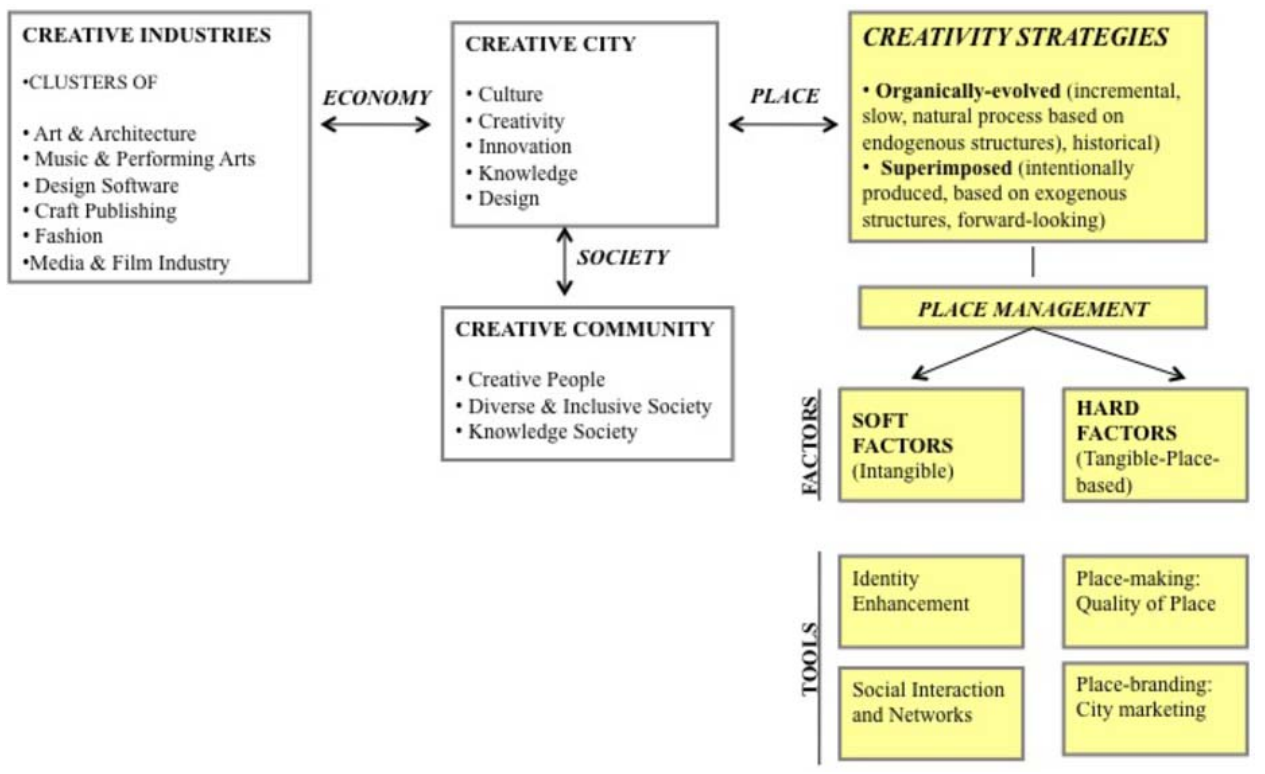

Source: Durmaz et al. (2008) and Durmaz (2015)

Creative strategies put into context above suggest a conceptual framework that links place management tools with the major components of creative city, creative industries, creative communities and creative strategies. Place management tools are indicated under the creative strategies, which consist of soft and hard factors. Soft factors indicate identity enhancement and social interaction and networks. On the other hand, there are two types of hard factors: place-branding strategies, aiming to promote/brand places through city marketing strategies and place-making initiatives, aiming to invest in quality of place through urban design. The importance of urban design and achieving the quality 
of place deserves a wider debate. Therefore, this is discussed in detail within a separate section in hard factors in the forms of physical interventions.

\subsection{Soft factors for place management}

\subsubsection{Identity enhancement}

The concept of identity associates our understandings of identity formation in social and psychological development that functions to provide a sense of belonging construct meaning, foster attachments and mediate change (Altman and Setha, 1992). Symbolic objects help us to ensure physical, social and psychological well-being of creative/knowledge workers, as well as contributing to their social reproduction and consumption needs. Such constructed soft factor echoes in securing the social and physical attachment to a certain place. This is crucial, especially today where capital, goods, people and culture flow globally and jeopardise the individuality and authenticity of places through varied taste, belief and cultural identity. In this respect, Kunzmann (2004) suggests mediation between local distinctiveness and global orientation for identity of developing creative city; there are some places with cultural identities that have evolved over a period of time. Such places emerge naturally and generally with a certain type of industry and worker accumulation. Identity enhancement through historic-led urban regeneration projects has been the focus of city authorities since 1980s. In order to compete effectively in the global market and to maximise their share of global capital, cities are in search of the best congruent vision. In this regard, regeneration projects are the most effectively and widely applied tool, especially those that aim to reveal the historic character of their cities. Since the late 1980s cities, including Izmir, have taken attempts to reconstruct a new city image and provide local economic development through regeneration projects.

\subsubsection{Social interaction and networks}

One of the important success conditions of an urban intervention for creative cites is to develop, enhance and sustain social interaction and networks. Bianchini and Ghilardi (2004) argue that social cohesion is difficult to achieve, as cities are marked by economic and lifestyle differences. Therefore, they suggest social interaction can be promoted between different groups by providing the opportunities to allow different social groups inhabit the same territory. The key issue is to enable an open -minded space, rather than a single -minded space through maximising the potential of cultural resources and enabling flexible uses and accommodating different users while allowing interaction. Further, as Bianchini and Ghilardi (2004) underline, it becomes much more important to achieve design cities through social interaction and intercultural exchange and innovative capacities of neighbourhoods. These interventions and the role of urban design and planning tools, whether through a policy-led or an organic approach, affect the development processes of creative city development. 


\subsection{Hard factors for place management}

\subsubsection{Place making: quality of place and services}

Quality of place is considered as a magnet for the creative/knowledge worker in creative cities; a strong quality of place experience is required to attract and retain certain type of people and industries. This includes recreational and cultural amenities, diversity of entertainment offerings and public transit and community safety, availability of healthcare so forth. People also want to live in places with a distinct identity and sense of place emerging from the unique stories and history of the community, distinctive natural and cultural heritage. According to Florida (2002), if a place is planned or designed to be an attractive and livable, there should be the dimension of quality of place, such as attributes of natural and constructed environment; diversity of people living in harmony in a tolerant environment and; vibrancy of social life, street life-outdoor activities should be considered in urban design and planning interventions. Baum et al. (2007) adds that a creative place should contain a unique built environment, diversity and openness, mix of leisure, public exhibitions and advertising in terms of quality of place.

Table 3 Urban preferences of knowledge workers

\begin{tabular}{lc}
\hline Types of knowledge workers & Attraction and preferences \\
\hline Nerds: scientists, engineers and creative professionals & Quality of university milieu \\
& Leisure facilities \\
& Hedonistic environments \\
& Accessibility \\
Bohemians: artistic/creative people, media/journalists & Lifestyle environments \\
& Affordable space \\
& Creative milieu \\
Students (latent knowledge workers) - freshmen, & Entertainment \\
graduates, visiting fellows and young members of & Urban diversity \\
staff and foreign knowledge workers & Cost of living \\
& Prestigious universities \\
& Lifestyle environments \\
& Cheap accommodation \\
\hline
\end{tabular}

Source: Baum et al. (2007)

Quality of place generates economic activity, provides spatial, aesthetic, cultural and psychological needs of people. In this regard, place management strategies attract particular attention in the pursuit of the competitive advantage providing the needs and desires of these specific group workers as symbolic analysts, i.e., manipulating symbols rather than machines (Reich, 1993). In such places, designers, actors, musicians, painters, dancers and the likes can be regarded as bohemians, similarly technology workers including scientists and engineers are known as nerds; students as latent knowledge workers and foreign knowledge workers, covering mostly researchers or $\mathrm{PhD}$ candidates on temporary contracts, complete the picture. Attractions and preferences of knowledge and creative workers and their expectations from the urban environment differ (Table 3), therefore it is important to investigate recent developments, especially in the inner city. 
Creative and knowledge are described in this study as those who work in creative and knowledge-intensive, design-based activities at particular city locations and are described as knowledge and creative workers.

\subsubsection{Place-branding and incubation of creativity}

A place-based concentrated creativity fosters uniqueness and distinctiveness of that place and draws talent and investment by improving the reputation and attractiveness of that place (Landry, 2000). Place branding is not only a logo or tagline of a city, but a process of developing strategies to succeed the long-term vision and objectives. Brands are constructed as a complex of factors, named as city brand hexogen, comprising people, policies, products, culture, business climate and tourist attraction (Evans, 2009; Prophet, 2006). Place branding is also a process of developing certain goals to achieve the long-term vision and objectives. It becomes easier to activate its opportunities and improve the weaknesses of the city in the competitive new world order. As cities come to resemble each other, the need for distinctiveness, reinventing, producing, or enhancing the identity forces them to construct a comprehensive strategy. New York, San Francisco, Barcelona, Istanbul, Rome and Venice are evolved organically and their urban identity based on built heritage, urban geography and history. In contrast, cities like Bilbao, Doha, Dubai and Las Vegas are the examples of cities whose characteristics were superimposed via innovative urban design, urban regeneration and place branding strategies that developed an artificial or produced identity. For example, today Dubai is emerging as an ultra modern city in the middle of a dessert, where the construction boom only started in 1990 s as a national government initiative. City plans, urban design and marketing campaigns turned Dubai into a famous city, with its conceptual islands, theme parks, film studios and stylish skyscrapers. The city authorities unveil Fujairah Creative City a media hub complete with new radio stations, a TV channel since 2005, a publishing industry. Another example is the city of Las Vegas. It is also national government initiative aimed the economic development of the city by legalising gambling, which transformed a small railroad company town into a world famous gambling and entertainment city (Douglass and Raento, 2004). Santa Fe, New Mexico is another good example of a successful place branding strategy. The city was subjected to one of the first city-based initiatives derived from creating an architectural style and a constructed identity, the so-called the myth of Santa Fe. This architectural style, created in 1930s, has been widely implemented since then. The building act and urban design principles developed to support that style augmented the creation of the stylish city. Additionally, successful promotion of place branding in Santa $\mathrm{Fe}$ exported these branding strategies to New York City (Wilson, 1997). Lastly, besides these large city-based projects, Guggenheim Museum at Bilbao, Spain is a successful example of producing an identity through innovative architectural design. The museum, with an iconic architectural style, transformed the old industrial town into a tourist-oriented cultural city and these induced effects are termed as Guggenheim effect in architecture and urban design literature.

Prophet (2006) presents some urban design criteria for a strong place branding shifting the perception of a place that may be suffering from a poor image among external and internal constituents; creating a common vision for the future of the community; providing a consistent representation of the place, to enhance its local, regional and global awareness and position and discarding unfavourable stereotypes associated with a place and make it more appealing (Prophet, 2006). 


\section{Case study in Izmir, Turkey}

The city of Izmir, located on the west coast of Turkey by the Aegean Sea, the third biggest city in Turkey with population of 3.9 million, has recently become familiar with the term creative city. Throughout the early past years, Izmir fell behind in the global inter-urban competition and began to lose appeal compared to other Mediterranean cities. In comparison to Istanbul, as a world city, Izmir has suffered an identity crisis and hardly appeared in the globalising urban network. Therefore, in 2009, Izmir Greater Metropolitan Municipality initiated a series of design-based activities and brought together the related professionals and academics from different sectors to plan a design-based development strategy. In 2009, a culture workshop was organised under the direction of Izmir Metropolitan Municipality. As a result, many creative people from various art and design fields, scientists and intellectuals from the academy and practice became aware of the identity enhancement attempts by the city and started to participate in this new vision, based on design and creativity for Izmir. It set out its mission on three bases; first, Izmir as the city of innovation and design; second, openness to international relations and importance of the vision through relationships with major cities of Mediterranean and finally, providing the vision in democratic and participatory practice. The overall atmosphere, including the physical and social spheres of Izmir, has started to develop into a more creative and design-based structure.

\subsection{Investigation of soft factors in Izmir}

\subsubsection{Identity enhancement attempts}

One prominent outcome of 2009 workshop was to improve the city vision through relationships with major Mediterranean cities. Therefore, Izmir Metropolitan Municipality formed the Mediterranean Academy as a department in order to support this vision and provide the city with culture, art and design. The academy's first aim was to improve cultural and historical activities. In May 2011, the design forum was held in order to decide on particular strategies to emphasise Izmir's identity as a creative city. The two outcomes of the forum were crucial; increasing the city's design capacity and increasing the awareness of and demand for design. In the discussions, the Coastline Urban Design Project (Izmir Deniz Project) was also initiated within these discussions. The academy has also become responsible for the promotion of organic agriculture and ecologic settlement design in the city due to its high potential in agriculture, possible contribution to sustainability. More recently, academic and practical design groups have been formed to improve design and creative activities in Izmir.

In addition to these attempts to reveal cultural identity, Izmir has a rich built heritage spanning different historical periods, which can be utilised to promote the economy, tourism and also to build a stronger city image. In this context, Izmir Greater Municipality currently employs the discourse of historical preservation to revitalise the city. In the historical centre eight special projects relate to the historical and cultural identity. These projects are

1 'Konak Square Special Project Area'

2 'Altın Yol Ancient Road Special Project Area' 
3 'Ancient Stadium Special Project Area'

4 'Ancient Theatre Special Project Area'

5 'Kadifekale Special Project Area'

6 'Ali Pasa Square Special Project Area'

7 'Hisarönü Mosque Special Project Area'

8 'Agora Special Project Area' (Taşkın et al., 2006).

Within this context, Konak Square was already redesigned in 2002 and historic axis connecting Konak Square through Kemeralti to Kadifekale has been regenerated. Considering these projects, it is possible to argue that Izmir is making progress towards a vision enhanced its historic identity through these historic-led regeneration projects, which could also benefit its creativity and design-related image and vision.

\subsubsection{Social interaction and networks}

Recently, several new initiatives and developments in Izmir have been initiated by individual entrepreneurs, creative people and some art-design-oriented institutions such as art galleries, exhibition and workshop spaces, innovative cafes, extended workspaces and artist in residence initiatives. These places and initiatives generate events in which creative people meet and socialise and exchange information, experiences, ideas and discuss future projects, daily news and community gossip. In this sense, they are important agents who incubate creativity.

K2 Contemporary Art Centre is an art gallery located in Alsancak. It is an independent organisation founded by individual artists in 2003. It offers a platform for artists to collaborate and share their products with public. The gallery's motivation is to bring together national and international artists and also offer public programs including seminars, lectures, performances, film and video screenings. There are permanent resident artist's studios and also several guest artists' studios. It is the first art venue in Izmir that is a self-organised and self-supported artist organisation.

Project Maquis initiated as a social interaction hub by a foreigner academic who works at Art and Design Faculty's Interior Design Department. It is a self-funded initiative that takes place in the entrepreneur's house in Kemeralti, the historic quarter of Izmir. He regenerated a historic house using the ground floor as an art gallery and the first floor as his home. The place hosts various international exhibitions and installations. The exhibitions enrich the social activities of Izmir and help to unite the design and artist community.

Origin founded by three entrepreneurs in 2016, is located at an old industrial site in Bornova. It offers brand-new workspaces with various facilities. There are offices which can be rented individually on the ground floor and on the first floor, shared open offices. The place also hosts artist and designer talks and aims to accommodate other events organised by member of the public, designers and academics in collaboration with other institutions and universities to further organise workshops, events, talks and seminars.

Nobon, founded by an architect, organises many creative events and design ideas in Izmir, including the Izmir Design Days and Festival Rendezvous (creative events and design festival) in Kültürpark, Panayır Design Market and also Pecha Kucha a worldwide trend in events first introduced in Izmir in 2014. Another event organised by the same 
person is Rendezvous, an all day event in Izmir in Kültürpark, the central park of Izmir and an important public gathering area and landmark in the city's urban memory. The event both aims to activate this park and also bring musicians and locals and enrich the social environment of Izmir.

Culture cafes: several new-age arty cafes have emerged in Izmir, which are also a hub for creative people, mostly located in the bohemian neighbourhoods of Izmir. Some historic buildings are soon to be converted to collaborative artist's spaces. In this sense, it has an emerging café culture scene that is known as one of the foundation of bohemian creative atmosphere, according to Montgomery (1997). Some of these are introduced below. No. 42 is located in 1472 Street, Alsancak, where several old-historic houses are in the process of renovation. Several other cafes have recently opened on this street, arguably attracted by no. 42. It is located in a historic house, with a designer shop on the ground floor. The place also hosts events, parties, art-markets, Panayır, bringing the creative artist community together. Students, artists, designers and academics also use the place as an extended workspace. Radio-Bar Edit in Izmir is the first Turkish radio-bar. Junker, also in Alsancak, is a cafe and meeting place for young entrepreneurs, for idea exchange and networking. No. 59 Bicura is a design product store including vintage clothing and objects and artisan fashion jewelry. 1456 Sokak and the nearby streets in Alsancak is becoming a significant design cluster with arty cafes, art galleries and artisan stores.

Additional events are also crucial for social interaction and networking. IF Wedding Fashion Izmir, \#izmirdeoluyor, which allows users to find arts and related activities in Izmir, graffiti events called Graffism, organised by Red Bull since 2012 and Talking Walls - Murals Project Bornova, can be given as examples. Talking Walls-Murals Project Bornova was the result of Bornova Municipality's efforts to bring design and innovation to the region in 2015. Graffiti art was produced in the form of murals in Yakakoy, a small district in Bornova. The project name is called 'Konuşan Duvarlar' or 'Talking Walls' with murals on 11 walls of occupied houses, designed by Furkan Sönmez, who has been a graffiti artist for ten years. The designs take inspirations from the nature and characteristics of Yakaköy.

\subsection{Investigation of hard factors in Izmir}

\subsubsection{Place-making: quality of place and services}

There has been investigation into quality of place in Izmir in order to explore factors in the attraction and retention of certain type of people and industries. The previous project, namely as Izmir Knowledge Society-based Development Strategy was funded by IZKA as a part of analysis study for Izmir Regional Development Plan 2014-2023, in which 231 subject-matter experts were invited to participate in the Delphi survey. $42 \%$ rate of return was achieved in a two-round Delphi survey with 20 multiple-choice questions. This survey has been conducted among the knowledge workers including the creative workers (IZKA, 2013b). The results show that the artistic and creative people described as bohemians under the knowledge workers type (see Table 3) are considered as the major driver of the creative city.

When asking how to attract and retain talented creative/knowledge workers as talents in Izmir, respondents reported attracting foreign direct investment as of importance to creating high quality job pool for knowledge-based works. Development of world class 
cultural and entertainment services was the key factor. Considering urban quality of life in Izmir, respondents gave great importance to well-design living and working environments alongside first-class ICT and transport infrastructure, which highlights the need for world-class facilities in knowledge-based innovative cities, i.e., quality is more important than quantity. These answers are already reflected in the built environment with Bayrakli area being developed as a new centre with high-rise, high-density mixed-use Class A office and residential spaces, as well as with the implementation of Izmir Coastal Renovation Project, which concerns integrating coastal line area through high quality open spaces and amenities (Öner and Pasin, 2015).

Figure 2 Which incentives that Izmir needs to attract and retain creative/knowledge workers? (see online version for colours)

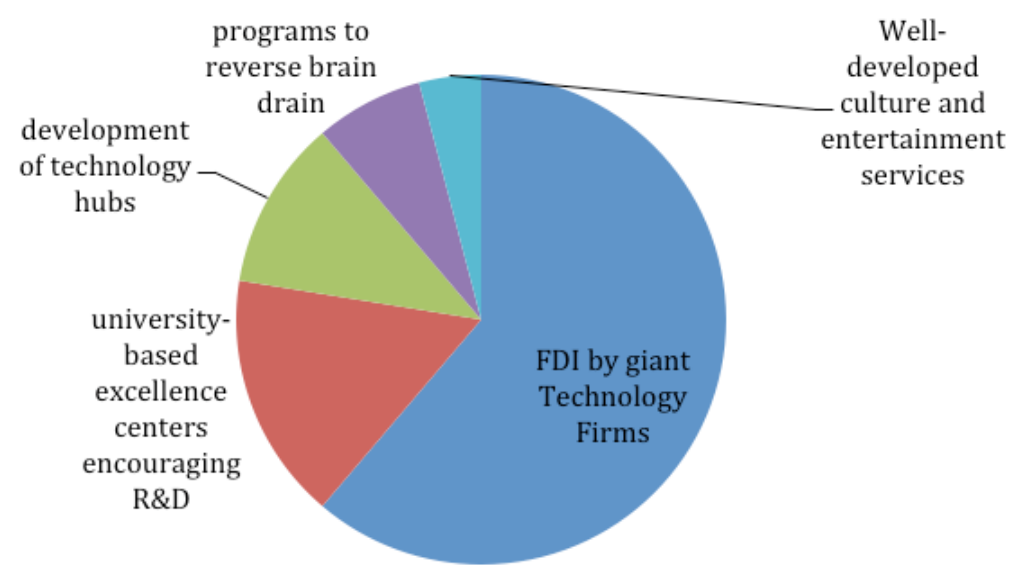

Figure 3 Which urban quality of life factors that Izmir needs to become innovate and creative city of Mediterranean basin? (see online version for colours)

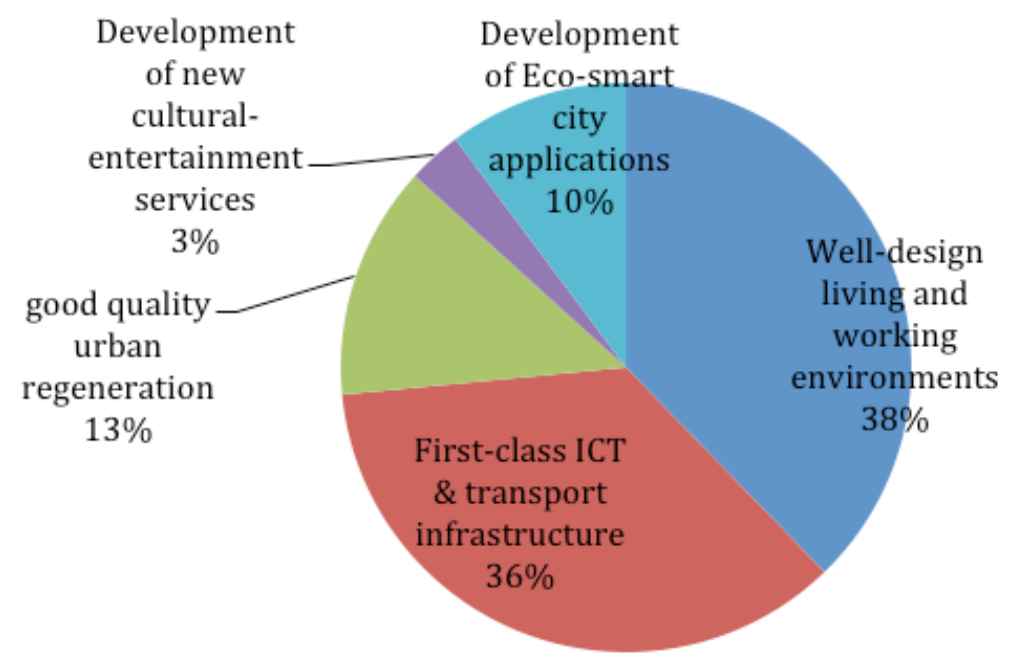


Figure 4 Which services/characteristics affect urban preferences of knowledge workers? (see online version for colours)

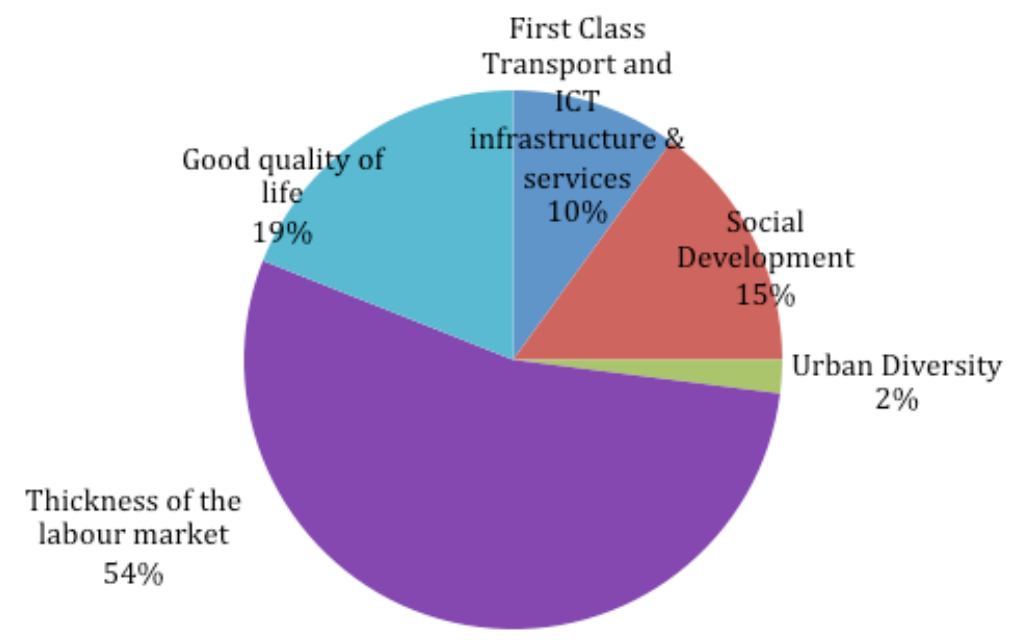

\subsubsection{Place-branding and incubation of creativity}

As explained so far, Izmir aims to improve its vision related to knowledge, design and creativity and several new efforts, initiatives, projects and developments have been implemented to achieve this vision. The municipality has undertaken several projects and commissioned various research studies such as Izmir Knowledge Society Strategy Research Report (2013b), Izmir Entrepreneurship Ecosystem Development Strategy (IZKA, 2013c) and Izmir City Marketing Strategic Plan. Furthermore, there are several governmental and non-governmental institutions that contribute to incubating creativity, knowledge and design. Some were initiated purposefully in the context of Izmir's visions supporting design and creativity and often have grown organically. These institutions are briefly described below:

- Institutional agents: eight universities in Izmir have architecture, design and art-related departments. Four are government-public university and four are private universities, half supported by foundations and half-funded by the government (Table 4). Combined, these schools contribute to the creative community approximately 1,000 graduates every year and also enrich the creative environment through different activities, workshops, seminars and conferences and project revisions. State universities are older; the first was established in 1955. The private institutions emerged after the 2000s and are associated with the recent developments in economics related to knowledge, creativity and art, as discussed earlier.

- Chambers-NGOs: several NGOs in Izmir collaborate with these universities, such as Chambers of Architects, Landscape Architects, City Planners and Chamber of Interior Designers. These chambers and universities enormously contribute to the creative ecosystem of Izmir and acts as the important incubating agents. Especially the Chamber of Architects, with its newly renovated building located in the port area, acts as the magnet and catalyser of creative activity. Particular to the fashion and textile as driver sectors of the city, there are Aegean Clothing Manufacturers 
Association (EGSD), Aegean Exporters Associations (EIB) and Association of Aegean Leather and Leather Products, which bring together the private sector and public institutions in order to improve the global positioning of the Turkish fashion and textile sector. Particularly, Izmir dominates the Turkish market for the wedding wear sector within the fashion production of the country. The conditions of the wedding wear sector specific to Izmir have been studied in the recent research reports (IZKA, 2009 2010, 2013a; IEU, 2013; Mengi and Velibeyoğlu, 2013).

- Other actors: for many years, Izmir has had a rich event scene, organised by art institutions and art centres. Numerous festivals have been organised in Izmir, such as International Puppet Festival, Izmir European Jazz Festival, International Art Biennial of Izmir, International Izmir Festival, International Theatre Days, Izmir Short Film Festival, Izmir International Sculpture Workshop. In addition to those organically evolved institutions including universities contribute to the visions and projects of Izmir, the Greater Municipality also contributes to incubating creativity, knowledge and design through projects such as History Design Atelier, Izmir Mediterranean Academy and IZKA.

- History Design Atelier is a governmental institution founded in February 2015by Greater Izmir Municipality within the Department/Branch of Historic Environment and Preservation Department. The project is initiated as part of Izmir history project, as explained in the previous sections. The atelier is located in an old-historic building donated to the municipality by the owners, on condition that it is used for academic, public and research purposes within the historic quarters of Izmir. The building has been redesigned as workshop, event and seminar venue for integrating the local community, i.e., residents, children, tourism industry traders, students, academics, designers and residences of Izmir.

- Izmir Mediterranean Academy was established by the Greater Metropolitan Municipality and currently cooperates with national and international agencies and entities and organises exchange programs and research trips. It aims to organise, support and encourage national and international scientific conventions, symposiums, conferences and similar events, as well as cultural events, festivals and contests directly required for the execution of the academy's purposes (Bekmezci and Seçal, 2015). It initiated projects and forum, including Izmir Mediterranean Academy initiated projects and forums since 2011, the first leading one was the Design Forum in 2011, Izmir Deniz Project which is the redesign of the Izmir Bay waterfront, and architecture and urban design project within National Design Corridors Idea Competition in 2014. The academy also organised the Symposium on History, Culture and Politics in the Mediterranean, Izmir Oil Symposium, The Attempt of Izmir Culture Platform and the exhibition of Polish kids called 'Let's Play', as contributing the promotion of World Industrial Design Day. The academy is still active in supporting the projects and proposals proposed by individuals and institutions with the intention of nurturing creativity and design potential of Izmir (Bekmezci and Seçal, 2015).

- IZKA was established with the aim of improvement of the cooperation among public sector, private sector and non-governmental organisations, ensuring effective usage of resources, stimulating the local potential, fostering the regional development and ensuring its sustainability and decreasing the inter-regional development disparities. 
It has its own core missions of innovation, impartiality, transparency, reliability, efficiency and participation for greater hinterland of Izmir (Bekmezci and Seçal, 2015).

Table 4 Institutional agents of creativity: art, design and architecture schools of Izmir

\begin{tabular}{|c|c|c|c|}
\hline University name & Related departments & Public/private & Foundation year \\
\hline $\begin{array}{l}\text { Izmir Institute of } \\
\text { Technology }\end{array}$ & $\begin{array}{l}\text { - Architecture } \\
\text { - Industrial design } \\
\text { - City and regional planning }\end{array}$ & Public & 1993 \\
\hline Dokuz Eylul University & $\begin{array}{l}\text { - Architecture } \\
\text { - City and regional planning } \\
\text { - Faculty of Fine Arts }\end{array}$ & Public & 1981 \\
\hline Ege University & - Landscape architecture & Public & 1955 \\
\hline Katip Çelebi University & $\begin{array}{l}\text { - Architecture } \\
\text { - City and regional planning }\end{array}$ & Public & 2012 \\
\hline $\begin{array}{l}\text { Izmir University of } \\
\text { Economics }\end{array}$ & $\begin{array}{l}\text { - Architecture } \\
\text { - Interior architecture } \\
\text { - Industrial design } \\
\text { - Textile and fashion design } \\
\text { - Visual communication design }\end{array}$ & Private & 2005 \\
\hline Izmir University & $\begin{array}{l}\text { - Architecture } \\
\text { - Interior architecture }\end{array}$ & Private & 2007 \\
\hline Yaşar University & $\begin{array}{l}\text { - Architecture } \\
\text { - Interior architecture }\end{array}$ & Private & 2001 \\
\hline Gedis University & $\begin{array}{l}\text { - Architecture } \\
\text { - Interior architecture }\end{array}$ & Private & 2008 \\
\hline
\end{tabular}

\section{Discussion and conclusions}

Districts, cities, regions and even countries with particular characteristics provide environments for individuals and firms to engage in design-based activities and creative endeavours in today's economic structure. Cities with both the hard and soft factors represent a strong place management base for creative development. Considering the previous case studies in the world, it can be argued that the complex relationship of two major interrelated factors, namely soft and hard factors, seem to determine the potential for the growth of creative cities. The soft factors are of a more qualitative nature and have become more important in the past two decades. Izmir has recently started a process of building a new path for its future vision, in cooperating design industries, strategies and their related actors in interaction and networking. Therefore, this study has explored the availability and characteristics of the soft and hard factors as components of place management in the case of Izmir and investigated soft factors: identity enhancement, 
social interaction and networks; as soft factors; place making: quality of place and place branding and incubation of creativity. Furthermore, the possible contribution of place management integrated with urban strategies has been presented for the case of Izmir. The case study presents several findings relating to both soft and hard factors.

The stage of development of Izmir case is classified according to the framework proposed by Evans (2009) that suggests four levels of development for the creative spaces based on the different levels of policy intervention in terms of public and private sector involvement; "dependent, aspirational, emergent and mature developments" [Evans, (2009), p.48]. In this context, Izmir can be framed as a dependent case as it is developed with direct public sector intervention (i.e., Design Forum held in 2011) according to Evan's classification. However, soft factors also followed this initiative and contribute to producing the social climate necessary for creative environments. Furthermore, we can argue that these soft factors are decisive and appear to contribute more to Izmir's creative environment compared to the hard factors. Despite the important initial role of hard factor interventions introduced by the municipality, there has been no meaningful follow up policy intervention by the municipality.

As for the soft factors, the place identity indicates experiences, behaviours and attitudes of the social and physical atmosphere of places. Izmir is rich in this regard, as can be seen through the identity enhancement attempts. Identity is usually crafted through built heritage and historic values, as well as supporting innovative architecture, as discussed by Gospodini (2004). In the case of Izmir, the aim was to emphasise the identity through historic-led urban regeneration projects and strategies to enhance the historic identity of Izmir, including Izmir History Project in 2013, Redesign of Konak Square in 2002and Regeneration of Kemeralti Traditional Bazaar and other specific project areas. Since 1980s, Izmir has demonstrated a development pattern aimed at identity, as discussed in Taşkın et al. (2006) and Eğercioglu and Taşçı (2016). The municipality's attempt to reveal the historic potential of Izmir, has been limited by the effect of the Great Fire in 1922, which left limited historic remains for such vision. As for innovative design strategies at various levels, redesign of Konak Square in 2002 and the Izmir Deniz Project in 2011 can be seen as examples on the urban scale. Unfortunately, we cannot track the reflections of these strategies at the architectural level and therefore these strategies lack the strength to shift the perception of place image in Izmir and create awareness in public for Izmir's Design City Vision.

Furthermore, social interaction and networking being the other dimension of soft factors, recent years have shown that Izmir has become activity-rich, through young entrepreneurs and activism and recent art and design-related individual initiatives, which illustrate organic-development through creative entrepreneur-led initiatives. In this context, these initiatives have led to important socio-cultural activities, which can attract creative and knowledge workers, such as leisure facilities, hedonistic environments, lifestyle environments, variety of entertainment venues and reasonable cost of living as suggested by Baum et al. (2007) Table 3, (i.e., Project Maquis, Nobon, Culture Cafes and events). Also, districts with full of cultural content appear as sites that can be converted to living labs, (i.e., Origin), a test-bed for technologies and living and working environments, (i.e., Project Maquis). Urban regeneration sites for inner-city areas may use seamless opportunities for work-live-play-learn environments and full of inspiration for creativity. However, the number of these initiatives is just a few which is not yet enough to create a public awareness and critical mass. 
As for hard factors investigated in the case of Izmir, particularly for place-making through quality of place and services, the study reveals that the city contains recreational and cultural amenities and a diversity of entertainment offerings. Achieving distinctive and competitive qualities are crucial to place-branding strategies. These strategies constitute key urban policy instruments for creative city formation. There have been crucial changes leading to Izmir being branded as a design city. In this regard, the design city vision has deliberately been imposed at the institutional level, notably in the 2009 and 2011 Design Forums organised by the Izmir Greater Metropolitan Municipality. The rich variety of institutional agents as drivers for such design-based growth include several NGOs, growing number of design-related academies and schools emphasise that Izmir is in the process of crafting a creative identity. Also, the survey results show that the knowledge and creative workers appreciate the vibrant life style and quality of place, seen in Izmir's rich café culture, art and entertainment venues and diversity of people residing in a tolerant and vibrant environment, rich social life, vivid street life as described as components of quality of place by Florida (2002).

All in all, the relationship of each element in the creative city formation is a complex balance of factors as important resources for development. Place management has been evaluated as an integrated process including soft and hard factors with some tangible and intangible characteristics that together cover major aspect of creative city formation. Future studies on the same subject may explore in more depth the sub-factors for both tangible and intangibles and discuss how the place management tools can be used to measure creativity through a checklist to evaluate a creative city from a more quantitative perspective.

\section{References}

Altman, I. and Setha, M.L. (1992) Place Attachment, Springer, New York.

Baum, S., Yigitcanlar, T., Horton, S., Velibeyoglu, K. and Gleeson, B. (2007) The Role of Community and Lifestyle in the Making of a Knowledge City, Urban Research Program Practice and Policy Paper 2, Griffith University, Brisbane, Australia.

Bekmezci, C. and Seçal, F. (2015) Institutional and Government Support for Art in Izmir, Unpublished Research Report, Izmir University of Economics, Izmir, Turkey.

Bianchini, F. and Ghilardi, L. (2004) 'The culture of neighborhoods: a European perspective', in Bell, D. (Ed.): City of Quarters: Urban Villages in the Contemporary City, pp.237-248, Routledge, New York.

Bulu, M. (2011) 'Measuring competitiveness of cities: Turkish experience', International Journal of Knowledge-Based Development, Vol. 2, No. 3, pp.267-281.

Cabrita, M.D.R., Cruz-Machado, V. and Cabrita, C. (2013) 'Managing creative industries in the context of knowledge-based urban development', International Journal of Knowledge-Based Development, Vol. 2, No. 4, pp.318-337.

Department of Culture, Media and Sport (DCMS) (2001) Creative Industries: The Regional Dimension, DCMS, London.

Douglass, W.A. and Raento, P. (2004) 'The tradition of invention: conceiving Las Vegas', Annals of Tourism Research, Vol. 31, No. 1, pp.7-23.

Durmaz, B., Yiğitcanlar, T. and Velibeyoğlu, K. (2008) 'Creative cities and the film industry: Antalya's transition to a Eurasian film centre', The Open Urban Studies Journal, Vol. 1, pp.1-10. 
Durmaz, S.B. (2015) 'Analyzing the quality of place: creative clusters in Soho and Beyoğlu', Journal of Urban Design, Vol. 20, No. 1, pp.93-124.

Eğercioglu, Y. and Taşçı, B. (2016) 'Comparison of urban conservation projects in historical city centers: Izmir history project and Raval urban regeneration project', International Journal of Cultural Heritage, Vol. 1, p.110 [online] http://www.iaras.org/iaras/filedownloads/ijch/2016/ 017-0001.pdf (accessed 24 May 2016).

Evans, G. (2009) 'From cultural quarters to creative clusters - creative spaces in the new city economy', in Legner, M. (Ed.): The Sustainability and Development of Cultural Quarters, Institute of Urban History, pp.32-59, Institute of Urban History, Stockholm.

Florida, R. (2002) The Rise of the Creative Class and How It's Transforming Work, Life, Community and Everyday Life, Basic Books, New York.

Gornostaeva, G. and Cheshire, P. (2003) 'Media cluster in London', Les Cahiers de L'institut d'amenagement et d'urbanisme de la Region d'ile de France, Vol. 135, No. 4, pp.151-60.

Gospodini, A. (2004) 'Urban morphology and place identity in European cities: built heritage and innovative design', Journal of Urban Design, Vol. 9, No. 2, pp.225-248.

Grant, K.A. and Chuang, S. (2012) 'An aggregating approach to ranking cities for knowledge-based development', International Journal of Knowledge-Based Development, Vol. 3, No. 1, pp.17-34.

Hesmondhalgh, D. (2002) The Cultural Industries, 1st ed., Sage, London and Thousand Oaks, California.

Higgins, M. and Morgan, J. (2000) 'The role of creativity in planning: the creative practitioner', Planning Practice and Research, Vol. 15, Nos. 1-2, pp.117-127.

Hutton, T.A. (2006) 'Spatiality, built form, and creative industry development in the inner city', Environment and Planning A, Vol. 38, No. 10, pp.1819-1841.

Izmir Development Agency (IZKA) (2009) İzmir kümelenme stratejisinin geliştirilmesi projesi Report, Izmir, Turkey.

Izmır Development Agency (IZKA) (2010) İzmir kümelenme stratejisinin geliştirilmesi projesi Report, Izmir, Turkey, ISBN: 978-605-5826-04-8.

Izmir Development Agency (IZKA) (2013a) İzmir mevcut durum analizi Report, Izmir, Turkey, ISBN: 978-605-5826-12-3.

Izmır Development Agency (IZKA) (2013b) Izmir Knowledge Society-based Development Strategy Report, Izmir, Turkey, ISBN: 978-605-5826-11-6.

Izmır Development Agency (IZKA) (2013c) İzmir Girişimcilik Ekosisteminin Geliştirilmesi Stratejisi, Izmir, Turkey, ISBN: 978-605-5826-10-9.

Izmir University of Economics (IEU) (2013) Uluslararası rekabetçiliğin geliştirilmesi projesi Report, Izmir, Turkey.

Jensen, O. B. (2005) 'Branding the contemporary city: urban branding as regional growth agenda?', Paper presented at Regional Studies Association Conference 'Regional Growth Agenda, Aalborg, May.

Kunzmann, K. (2004) 'Culture, creativity and spatial planning', Town Planning Review, Vol. 75, No. 4, pp.383-404.

Landry, C. (2000) The Creative City: A Toolkit for Urban Innovators, Comedia, London.

Lash, S. and Urry, J. (1994) Economies of Signs and Space, Sage, London.

Mengi, O. and Velibeyoğlu, K. (2013) 'Wedding wear cluster in Izmir: how does the creative knowledge ecosystem self-operate?', in Yiğitcanlar, T. and Bulu, M. (Eds.): Proceedings of the 6th Knowledge Cities World Summit, KCWS 2013, Lookus Scientific, Istanbul, Turkey, pp.21-35, ISBN: 978-9944-380-11-9.

Montgomery, J. (1997) 'Café culture and the city: the role of pavement cafés in urban public social life', Journal of Urban Design, Vol. 2, No. 1, pp.83-102.

Montgomery, J. (2005) 'Beware the creative class, creativity and wealth creation revisited', Local Economy, Vol. 20, No. 4, pp.337-343. 
Öner, A.C. and Pasin, B. (2015) 'Emerging towers in Bayrakli: sustainability as a branding strategy or a tool for local development?', Buildings, Vol. 5, pp.834-859.

Prophet, M. (2006) Branding your City Report, Online Research Report [online] http://www.ceosforcities.org (accessed 14 August 2016)

Reich, R.B. (1993) The Work of Nations, Alfred A. Knopf, New York.

Wilson, C. (1997) The Myth of Santa Fe: Creating a Modern Regional Tradition, University of New Mexico Press, Albuquerque.

Taşkın, Ö., Güçer, E., Kompil, E., Durmaz, B. and Can, I. (2006) 'Transformation of urban public space in reinventing local identity', in 42nd ISOCARP Congress, pp.1-11 [online] http://www.isocarp.net/Data/case_studies/852.pdf (accessed 12 January 2016).

Yagoubi, A. and Tremblay, D.G. (2017) 'Cooperation and knowledge exchanges in creative careers: network support for fashion designers' careers', International Journal of Knowledge-Based Development, Vol. 8, No. 1, pp.24-46.

Yigitcanlar, T., Guaralda, M., Taboada, M. and Pancholi, S. (2016) 'Place making for knowledge generation and innovation: planning and branding Brisbane's knowledge community precincts', Journal of Urban Technology, Vol. 3, No. 1, pp.115-146.

Yusuf, S. and Nabeshima, K. (2005) 'Creative industries in East Asia', Cities, Vol. 22, No. 2, pp.109-122. 